DOI:https://doi.org/10.38047/rct.v13.FC.2021.al11.p.1.23

\title{
"O CETRO DAQUELES QUE SOFREM A OPRESSÃO DOS PONTENTADOS": JORNAIS MANUSCRITOS E IMPRESSOS NA CONSTRUÇÃO DE UMA MICROESFERA PÚBLICA EM RORAIMA
}

\author{
"THE SCEPTER OF THOSE WHO SUFFER THE OPPRESSION \\ OF THE POTENTATES":MANUSCRIPTS AND PRINTED \\ PAPERS IN THE CONSTRUCTION OF A PUBLIC MICROSPHERE IN RORAIMA
}

\section{Prof. Dr. Luís Francisco Munaro (UFRR) ${ }^{1 *}$ \\ Me. Cyneida Menezes Correia (UFRR) ${ }^{2^{*}}$}

\section{Resumo}

Este artigo descreve as primeiras iniciativas jornalísticas na vila de Boa Vista, hoje capital do estado de Roraima, limitadas ao período que vai de 1907 a 1918. Trata-se de um curto período de circulação de jornais locais, logo substituídos por jornais vindos da capital do estado do Amazonas, Manaus. Estes jornais locais foram publicados graças ao empenho individual de uns poucos elementos letrados, entre os quais o educador Diomedes Souto Maior e o bispo Gerardo Von Caloen. Ao mesmo tempo em que permitem ver os poderes políticos e a constituição social da pequena vila, também permitem compreender os planos e projetos utópicos que orientavam a conduta da elite em processo de formação, e sua missão autoconcedida de levar a civilização para os sertões "lutando contra a opressão dos potentados".

Palavras chaves: História dos jornais; Roraima; manuscritos; República; letramento.

\section{Abstract}

This article describes the first journalistic initiatives in the village of Boa Vista, capital of today's state of Roraima, limited to the period from 1907 to 1918. It is a short period of circulation of local newspapers, soon replaced by newspapers from the capital Manaus. These local newspapers were published thanks to the individual efforts of a few literate people, including the educator Diomedes Souto Maior and Bishop Gerardo Von Caloen. At the same time that it allow us to see the political powers and the social constitution of the small village, it also allow us to understand the utopian plans and projects that guided the conduct of the elite in the process of formation, and its self-granted mission of taking civilization to the hinterlands "fighting against the oppression of potentates".

Keywords: History of newspapers; Roraima; manuscripts; Republic; literacy.

\footnotetext{
${ }^{1 *}$ Atualmente, é professor adjunto IV do curso de Jornalismo da Universidade Federal de Roraima e professor do Programa de Mestrado em Comunicação na mesma instituição, onde oriento dissertações de mestrado.

2* Graduada em Letras e em Jornalismo pela Universidade Federal de Roraima, obteve grau de mestra em Comunicação pela mesma instituição. Atualmente, é assessora de comunicação no Palácio de Governo em Roraima.
} 
Revista do Programa de Pós-Graduação em História da Universidade Federal do Amazonas Volume 13. 2021. 


\section{INTRODUÇÃO}

Este artigo descreve os primeiros jornais disponíveis no atual estado de Roraima, buscando, na medida do possível, compreender como ajudaram na formação de uma embrionária elite intelectual local. Eles foram descritos na obra "Rios de Palavras" 3 , bem como na dissertação recentemente publicada com o nome de "Jornalismo e memória: a construção da política nos jornais de Roraima (1907-1988)" da autoria de Cyneida Correia ${ }^{4}$. Este último trabalho ajudou a entender o papel das folhinhas manuscritas na dinâmica da vida local, folhinhas copiadas uma a uma de forma cuidadosa, por escritores que não foi possível, no âmbito da dissertação, conhecer com mais detalhe, posto que se apresentavam sempre sob pseudônimos. Já entre os impressores de jornais, estão elementos políticos mais conhecidos da vida na vila de Boa Vista, como o professor Diomedes Souto Maior e o Bispo Gerardo von Caloen, que assumiram ativo papel político, social e intelectual. Diomedes, ao longo de boa parte da primeira metade do século XX, Gerardo no curto espaço de 1914 a 1918. O primeiro destacou-se como um pioneiro das atividades de ensino público e o segundo como missionário beneditino. No intervalo entre a publicação destes jornais e a criação do Território Federal de Roraima, em 1943, são registradas poucas (ou nenhuma) iniciativas jornalísticas e educacionais que permitam refazer o percurso da formação de uma "intelectualidade local" mais ou menos consciente do seu lugar na nação (ou, quando muito, na região amazônica). Isso ocorre por conta de um incêndio no setor de arquivo da Imprensa Oficial de Roraima, que deu fim à história de vários dos jornais que possam ter passado pelo estado nesse período.

Dadas as lacunas de publicações locais, a maior parte dos jornais lidos pelos círculos alfabetizados provinham de impressores no Amazonas, caso do maior jornal dos anos 1950, O Átomo, impresso em Manaus. Em alguns casos, como no do Prof. Diomedes, há o registro de que ouvia a rádio $\mathrm{BBC}$ em busca de informações na década de 1930. Também os serviços postais ajudavam a tornar Boa Vista menos isolada do restante do país, sendo as corredeiras de Caracaraí um obstáculo constantemente mencionado pelos administradores locais para a chegada de embarcações com mercadorias e notícias. O governo de Getúlio Vargas, a partir de 1930, deu início a uma série de empreendimentos federais para estender os poderes centrais nos quatro cantos do país, permitindo a ocupação do território pela máquina governamental e a universalização da alfabetização por meio da atuação do estado. As iniciativas também contaram com ativo financiamento de atividades impressas, com a tentativa de inscrever os intelectuais na busca pela definição de uma consciência nacional passando pela formação de uma intelligentsia propriamente dita ${ }^{5}$.

Através da identificação destes homens de jornais e do papel que tiveram na construção da vila, buscaremos compreender se é possível falar numa consciência de

\footnotetext{
${ }^{3}$ MUNARO, Luís Francisco (org.). Rios de palavras: a imprensa nas periferias da Amazônia. Porto Alegre: Editora Fi, 2016.

${ }^{4}$ CORREIA, Cyneida Menezes. Jornalismo e memória: a construção da política nos jornais de Roraima (1907-1988). Dissertação de mestrado apresentada à Universidade Federal de Roraima, 2021.

${ }^{5}$ MUNARO, Luís Francisco. Coronéis, jornais e a formação dos municípios no Amazonas. Revista Observatório, Palmas, 2018. Disponível em: https://sistemas.uft.edu.br/periodicos/index.php/observatorio/article/view/5223 (Acesso em 06/2021).
} 
pertencimento à Amazônia. Faremos o percurso, em primeiro lugar, tentando compreender de forma mais detalhada as atividades de ensino que permitiram alguma alfabetização e a gestação de um círculo regular de leitores; em segundo lugar, dos primeiros jornais manuscritos que supriam a lacuna dos impressos e fornecem indícios sobre o funcionamento da vila no velho esquema do coronelismo; e, em terceiro, dos jornais impressos propriamente ditos e sua inscrição no "Brasil republicano" que se buscava, aos trancos e barrancos, construir.

\section{Algumas pistas sobre as práticas de alfabetização}

A colonização de Roraima mistura a presença de militares com o objetivo de defender as zonas fronteiriças de incursões de espanhóis, holandeses e ingleses; a criação de fazendas de gado que cresceram exponencialmente com o boom do comércio da borracha; as atividades missionárias e catequéticas de capuchinhos, franciscanos e carmelitas; e, evidentemente, as várias comunidades indígenas, cujas formas e dinâmicas de interação são conhecidas mais a partir de seus conflitos com os militares e fazendeiros. Como de praxe na região amazônica, a alfabetização e a formação de um pequeno grupo de letrados é protagonizada pelo ensino católico, que começa a ser substituído de forma mais sistemática pelo ensino leigo a partir dos anos de Getúlio Vargas. A vila de Boa Vista, principal povoado do hoje estado de Roraima, contava, ainda em 1925, em torno de 1200 habitantes segundo o relato de Hamilton Rice ${ }^{6}$. A expedição de Rice, intitulada "Expedição à Guiana Inglesa", contou com um avião monomotor e rendeu inúmeras fotografias de Roraima e seus interiores. Numa delas, feita de dentro do avião, é possível ver a vila de Boa Vista. Trata-se de uma visão magnífica: a pequenina vila em meio a uma imensa charneca, que pode ser alcançada apenas durante as cheias do rio Branco, principal tributário do rio Negro.

\footnotetext{
${ }^{6}$ RICE, Hamilton. Exploração na Guiana Brasileira. Belo Horizonte/São Paulo: Ed.Itatiaia/EDUSP, 1978.
} 


\section{Figura 1}

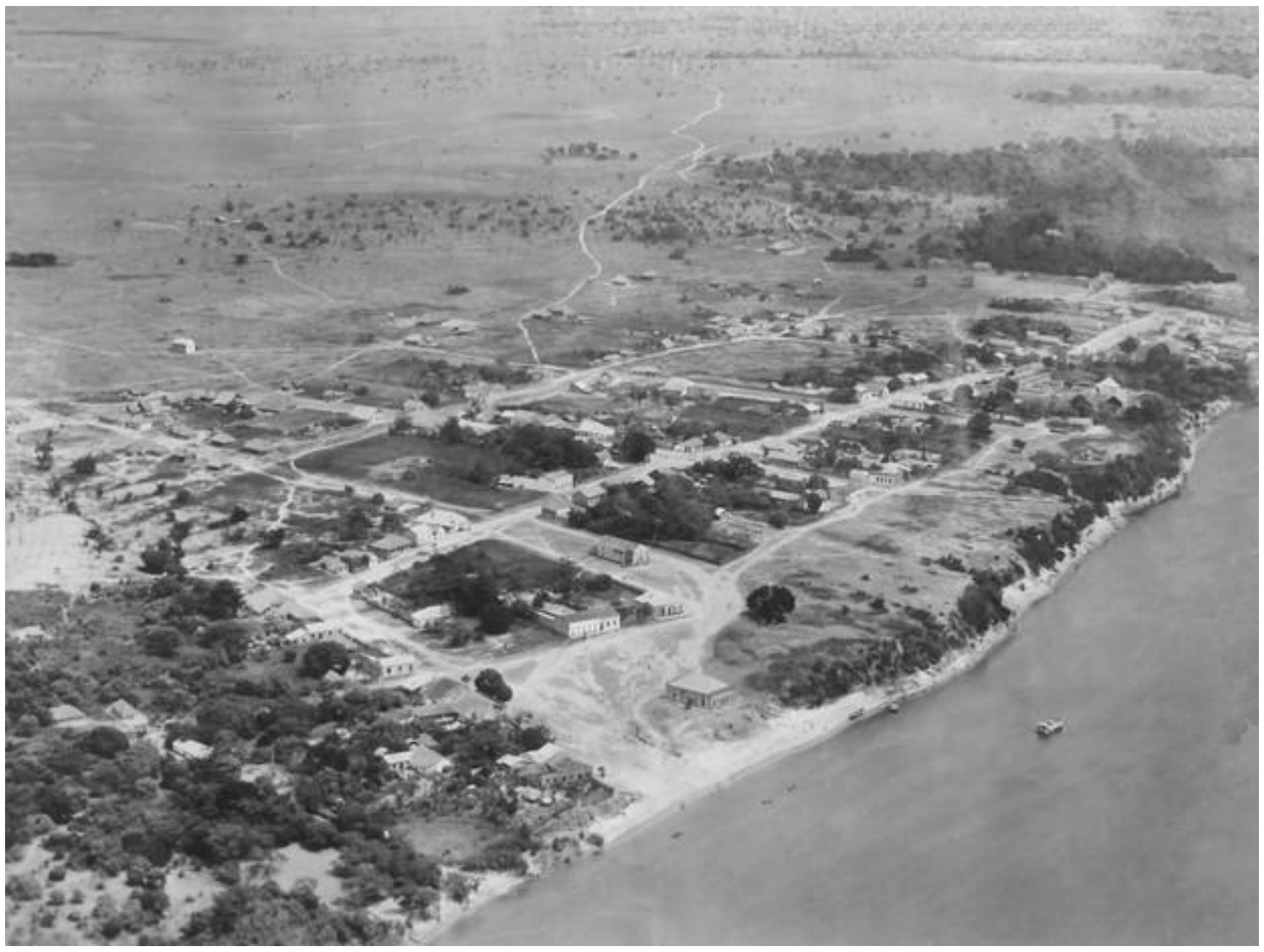

Fotografia da Vila de Boa Vista do alto tirada em 1924/1925. Fonte: Hamilton Rice, 1974.

Em 1725, os padres carmelitas construíram uma capela no local, fornecendo incentivo para a povoação. Depois deles, os franciscanos assumiram as atividades missionárias e construíram, em 1858, a Igreja Matriz, consolidando o núcleo de povoamento de Boa Vista. As atividades franciscanas duraram até 1909 quando foram substituídas pelas beneditinas. Em 1907, a região do Rio Branco se tornou "Prelazia da Abadia de São Bento do Rio de Janeiro", o que quer dizer, simplificando, que Boa Vista teria como prelado titular o bispo D. Gerardo van Caleon, chegado ao Brasil em 1895. Segundo Vanthuy Neto, Gerardo morou em Boa Vista entre 1914 e 1918, iniciou as obras de reconstrução da Igreja Matriz do Carmo, comandou "a missão no meio dos Povos Indígenas no Surumú, trouxe a linha de telégrafo e fundou a Sociedade de Melhoramentos do Rio Branco, no Rio de Janeiro"7 . Além do papel educacional, Gerardo escreveu a parte doutrinal do Jornal O Boa Vista, como veremos adiante.

No que concerne ao ensino, o importante papel desempenhado pelos monges foi atestado por Theodor Koch-Grunberg, etnólogo que esteve em exploração na bacia do Rio Branco entre os anos de 1911 e 1913. Grunberg descreveu as missões e alguma coisa da educação liderada pelos missionários beneditinos como um processo que envolvia

7 NETO, Vanthuy. História cronológica dos bispos de Roraima. S/d Disponível em: https://diocesederoraima.org.br/index.php/diocese-2/ (Acesso em 06/2021). 
várias tensões com os fazendeiros, sobretudo com o Coronel Bento Brasil, ressentido com a concessão da fazenda Calungá aos intrusos ${ }^{8}$. Evidentemente, fazendeiros e missionários buscaram tecer diferentes relações com os indígenas: os primeiros buscando força de trabalho e os segundos novos cristãos. Outro aspecto que deve ser salientado são as intensas relações inter étnicas que permitem a formação de relações de apadrinhamento, com a convivência de descendentes mestiços que são o fundamento destas sociedades híbridas.

A perseguição aos monges esteve ligada não somente aos interesses em torno de terras, mas também a conflitos envolvendo as atividades maçônicas do Coronel Brasil, que fundou a loja Paz e Progresso em conjunto com mais 48 membros. Como lembra Koch-Grunberg, sobre o período, podia-se mesmo falar numa campanha contra os missionários, movida inclusive através de acusações da pior espécie nos jornais: "soldados da polícia de Manaus implantaram um regime de terror junto ao Rio Branco perseguindo todos que simpatizavam com os padres. Em princípios de 1910, chegaram inclusive a disparar vários tiros na casa onde estavam hospedados" ${ }^{\text {. }}$. Saídos da região de Boa Vista em 1915 diante das pressões dos coronéis e da inviabilidade de realizar suas funções religiosas, os beneditinos acabaram voltando em 1915, ainda sob o comando de D. Gerardo Von Caleon, que desta vez procurava não apenas apaziguar os ânimos como também explorar comercialmente a região. Como constatou Jaci Vieira, Gerardo ajudou a fundar uma sociedade sem fins lucrativos denominada "Sociedade de Melhoramentos do Rio Branco", que teria como fim único, segundo seus estatutos, zelar pelos interesses gerais da região e dos seus habitantes ${ }^{10}$.

Ainda na informação fornecida por Jaci Vieira, em palestra na sociedade de agricultores do Rio de Janeiro em 1918, Dom Gerardo mencionou a importância do saneamento básico de forma a tornar as condições de vida mais salubres e mesmo servir o povoamento, no topos comum desde os governadores de província, passando pela importante obra de Torquato Tapajós sobre a "colonização e imigração". Pode-se, neste sentido, dizer que Caleon é um pioneiro nesse tipo de estudo em Boa Vista, ao mencionar as dificuldades da colonização, a necessidade do incentivo governamental, a busca pela integração sistemática do vale do Rio Branco no corpo da nação. Também assumiu, no conflito entre fazendeiros e indígenas, uma postura mais próxima dos primeiros, colocando-se favorável à demarcação de terras ${ }^{11}$. Gerardo teria se colocado, assim, mais como estadista do que como um missionário, pensando em fazer dos indígenas "bons

\footnotetext{
${ }^{8}$ KOCH-GRÜNBERG, Theodor. Do Roraima ao Orinoco. V. I, São Paulo: Editora UNESP, 2003.

${ }^{9}$ IN VIEIRA, Jaci Guilherme. Missionários, fazendeiros e índios em Roraima: a disputa pela terra - 1777 a 1980. 2003. Tese (Doutorado). Programa de Pós-Graduação em História, Universidade Federal de Pernambuco, Recife, 2003, p. 99.

${ }^{10}$ VIEIRA, Jaci Guilherme. Missionários, fazendeiros e índios em Roraima: a disputa pela terra - 1777 a 1980. 2003. Tese (Doutorado). Programa de Pós-Graduação em História, Universidade Federal de Pernambuco, Recife, 2003, p. 99, p. 107.

11 VIEIRA, Jaci Guilherme. Missionários, fazendeiros e índios em Roraima: a disputa pela terra - 1777 a 1980. 2003. Tese (Doutorado). Programa de Pós-Graduação em História, Universidade Federal de Pernambuco, Recife, 2003, p. 105.
} 
cidadãos brasileiros". Como veremos, a postura do "Jornal de Boa Vista" acabou por espelhar, sobretudo na sua parte doutrinal, estas preocupações de D. Gerardo.

A partir da década de 1920, a missão beneditina direcionou as suas atividades para a vila de Boa Vista, comprando uma casa para os padres e alugando uma para as freiras, que trabalhavam na escola São José. O segundo prelado do Rio Branco, Dom Pedro Eggerath, alemão, construiu na década de 1920 "a sede da Prelazia, o hospital Nossa Senhora de Fátima, a Escola São José, o internato para jovens no Calungá, a residência das Irmãs Beneditinas, hoje Casa João XXIII, fez a $1^{\text {a }}$ estrada Boa Vista - Caracaraí, trouxe para cidade uma fábrica de carne enlatada e a energia elétrica" ${ }^{12}$. Em 1943, o Presidente da República desmembrou a Bacia do Rio Branco do Estado do Amazonas, constituindo o Território Federal do Rio Branco. Mandou que os monges beneditinos colhessem todo material etnográfico e antropológico dos índios do rio Branco, o que demonstra como os missionários ainda eram elementos importantes da elite intelectual e política do período.

Koch-Grunberg também nos informou a respeito do aprendizado que acontecia no interior das fazendas, como no caso de uma esposa de fazendeiro ou por preceptores que podiam alfabetizar as crianças que habitavam as proximidades ${ }^{13}$. Na ausência do estado como produtor de uma alfabetização uniforme, burocraticamente regulamentada, os ensinos doméstico e religioso supriam lacunas e, por assim dizer, integravam estas regiões distantes no Brasil. Dentre os pioneiros do ensino leigo estão figuras como o primeiro prefeito do município de Boa Vista, João Capistrano da Silva Mota, sargento do exército que chegou no território do Vale do Rio Branco e aqui viveu até seu falecimento, e Alfredo Venâncio de Souza Cruz, filho de portugueses migrados para o Brasil que veio a Boa Vista em torno de 1848 para administrar o Forte de São Joaquim, deixando para os filhos a Fazenda "Paraíso". Além deles, é de vital importância o nome de Diomedes Souto Maior, atestada na nomeação de uma das duas escolas mais antigas em atividade em Boa Vista, em 1945, como Escola Estadual Diomedes Souto Maior, mesmo ano da instalação da Escola Estadual Lobo D’Almada. Os três homens foram professores e pioneiros nas iniciativas educacionais, ao lado dos supracitados monges. Entendido este pano de fundo educacional, buscaremos compreender a instalação e a circulação de jornais, sabendo que, entre os principais “jornalistas” estão o Prof. Diomedes e o Bispo Von Caleon.

\section{Os manuscritos}

Na conta de Roberto $\operatorname{Santos}^{14}$, em torno de $67,9 \%$ da população amazônica ainda não estava alfabetizada na década de 1910. Sebastião Monteiro, mais atento ao ambiente

12 NETO, Vanthuy. História cronológica dos bispos de Roraima. S/d Disponível em: https://diocesederoraima.org.br/index.php/diocese-2/ (Acesso em 06/2021).

${ }^{13}$ KOCH-GRÜNBERG, Theodor. Do Roraima ao Orinoco. V. I, São Paulo: Editora UNESP, 2003.

${ }^{14}$ SANTOS, Roberto. História econômica da Amazônia. 1800-1920. São Paulo: T.A. Queiroz, 1973. 
local de Roraima, sugere que $95 \%$ da população era analfabeta ${ }^{15}$. Essa estimativa significa a informação algo desoladora que, nesse período, na vila de Boa Vista, havia algo em torno de uma ou duas centenas de indivíduos alfabetizados, número que aumentaria substantivamente com as primeiras escolas de ensino lideradas pelos missionários, uma masculina e uma feminina, com capacidade para 160 alunos. Neste cenário de pouca mobilidade social, e no contexto de uma vila ainda incipiente, os manuscritos foram um recurso local importante para compensar a ausência de máquinas tipográficas. A rede de textos manuscritos guarda características muito peculiares, a começar pelo fato de dizer respeito a uma prática que se extinguiu há muito tempo: a cópia sui generis de material, num esforço artesanal que hoje pareceria absolutamente contraproducente. O que levava um indivíduo, na isolada vila de Boa Vista, diante de um "público" de umas poucas pessoas, copiar 50 vezes um mesmo material de quatro páginas? Os primeiros artífices desta forma de comunicar, os monges, desenvolveram a prática de copiar silenciosamente manuscritos clássicos ou sagrados, deixando-os à disposição da posteridade. Prática bem conhecida e aceita durante o período de instalação da cristandade. No caso dos copistas de notícias, a intenção era mais diretamente política. Como lembra Marialva Barbosa, as folhas manuscritas que surgiram a partir de meados do século XIX no Brasil buscavam interferir nos rumos da vida política, demonstrando proximidade com o partido Liberal ou criticando a situação social durante o Império ${ }^{16}$. Aqueles jornais manuscritos ainda hoje acessíveis em Boa Vista foram compilados e descritos pela pesquisadora Cyneida Correia $^{17}$, cuja dissertação possui um quadro descritivo de cada um deles, interessandonos aqui apenas o contexto e a possível intenção de cada publicação, ou seu significado, o porquê de ela estar circulando. Os três manuscritos aqui mencionados pertencem à década de 1907: O Caniço, Tacutu e A Escova. Há ainda os registros de outros nomes de jornais manuscritos que teriam circulado em torno do mesmo período, como O Carvão, O Sabiá e O Graveto, que não foi possível acessar.

O primeiro deles, denominado "O Caniço", possuiu periodicidade quinzenal e a tiragem anunciada de 50 exemplares, sendo seu redator-chefe intitulado "Passarinho" e seu colaborador "J. Justo" 18 , não sendo possível afirmar com segurança quanto tempo durou, já que não há nenhum registro histórico confiável até agora conhecido. 50 exemplares, como vimos mais acima, era um número bastante significativo. Não é demais mencionar, a título de comparação, que o primeiro jornal brasileiro, o Correio Braziliense, provocou um verdadeiro alvoroço na Corte portuguesa e mesmo transformou para sempre a política no Brasil com 200 exemplares mensais. No caso do Caniço, a edição que foi possível acessar, através da dissertação de Cyneida Correia, contém

${ }^{15}$ OLIVEIRA, Sebastião Monteiro. Origem e organização do sistema de ensino e as políticas de formação docente no estado de Roraima. Tese de doutorado apresentada na UNINOVE, 2016. Disponível: https://bibliotecatede.uninove.br/handle/tede/1538 Jun/2021, p. 43.

${ }^{16}$ BARBOSA, Marialva, Os manuscritos do Brasil: cenários de uma escritura. IN: Anais do XXXVII Congresso Nacional de Ciências da Comunicação. Foz do Iguaçu, 2014.

${ }^{17}$ CORREIA, Cyneida Menezes. Jornalismo e memória: a construção da política nos jornais de Roraima (1907-1988). Dissertação de mestrado apresentada à Universidade Federal de Roraima, 2021.

${ }^{18}$ CORREIA, Cyneida Menezes. Jornalismo e memória: a construção da política nos jornais de Roraima (1907-1988). Dissertação de mestrado apresentada à Universidade Federal de Roraima, 2021. 
elementos sobre a política local e estadual. Em duas colunas e com uma caligrafia compreensível, a edição diz, em citação integral, com a gramática atualizada:

O Rio Branco. Não podendo deixar a causa de que fizemos eco na imprensa, glória temos em noticiar aos nossos amáveis leitores que sua Exa. o Governador do Estado promete principiar para o engrandecimento desde lugar a canalização do ***.

Este será o primeiro ato de sua Exa. para esta terra, prova evidente de que não se esquecerá deste abençoado torrão. O município, desde que teve a felicidade de ter como chefe o Sr. Cel. Bento Brasil vai tomando proporções animadoras.

Sendo os impostos pagos aqui, já se se correr algum dinheiro e todos os empregados públicos estão satisfeitíssimos.

Teremos que ver em muito breve o Rio Branco levantar-se ante a crise assustadora por que estava passando devido à má diretriz de seu antecessor $^{19}$.

\section{Figura 2}

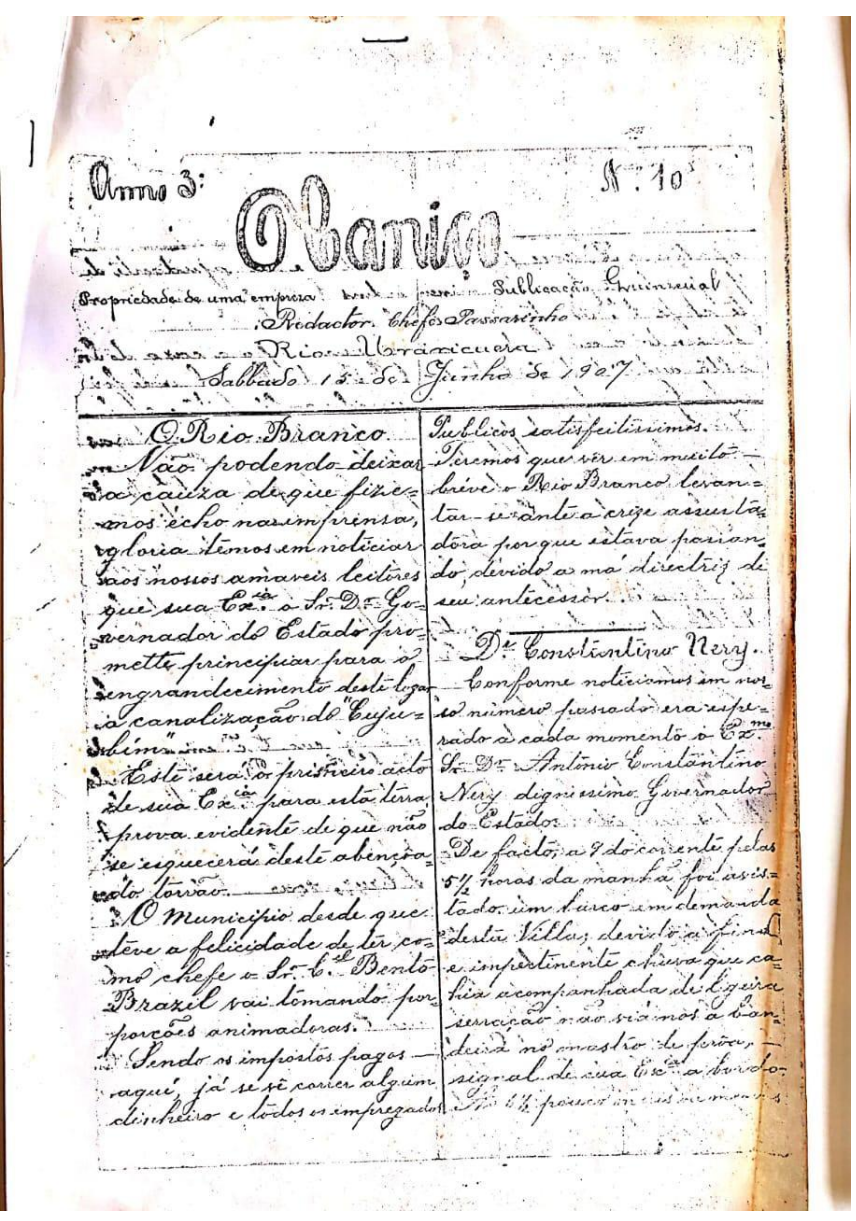

Jornal Caniço, 1907. 774 X 1032, cor: tons de cinza (com a ação do tempo a cor ficou sépia, Fotografia retirada do exemplar encontrado no Museu de Roraima. Fonte: Cyneida Correia.

\footnotetext{
${ }^{19}$ O Caniço, Boa Vista, 1907, p. 1.
} 
O Governador a que o redator Passarinho se refere é Antonio Constantino Nery, que governou o Amazonas entre 1904 e 1908. A celebração da política estadual é constante nestes jornais. No esquema performativo da política na primeira República (1889-1930), os "coronéis" manipulavam a política local, angariavam votos e mediavam conflitos, garantindo o poder do governador em nível estadual. Sendo, ao fim e ao cabo, este último que possuía os recursos econômicos para as benfeitorias públicas, de forma que, como habitualmente se diz, os coronéis disputavam "migalhas do poder central". Tratava-se, portanto, de uma relação de mutualismo entre indivíduos próximos, geralmente membros dos mesmos partidos republicanos que atuavam como clubes da elite.

O Coronel Bento Brasil, citado na matéria, é um personagem importante nesta história. Prefeito de Boa Vista entre 1917 e 1921, quatro vezes deputado estadual representando o município de Boa Vista do Rio Branco na Assembleia amazonense, senador, dono de uma das primeiras e maiores fazendas de Roraima, moderador de conflitos locais e membro-fundador da loja maçônica local. Como descrito na passagem, é uma "felicidade" ter o Coronel Bento como chefe, elogios e encômios que vão se repetir nos jornais impressos de alguns anos depois. Desde a morte do importante fazendeiro Sebastião Diniz, dois grupos disputaram o poder local, um em torno do coronel Bento Brasil e outro em torno de Coronel Cordeiro Cruz Saldanha. Não há muitas informações disponíveis a respeito do segundo deles, enquanto o primeiro é abundantemente mencionado como um dos fundadores de Boa Vista. Por outro lado, Hamilton Rice, em sua viagem de 1924, descreveu a rivalidade do Coronel Bento Brasil com J. G. Araújo, um empreendedor de relativo sucesso sediado em Manaus e proprietário de terras no Rio Branco (inclusive ativo financiador de produção cultural):

Seus domínios compreendem a maior parte dos terrenos da margem esquerda do Branco e do Uraricoera, desde Boa Vista até a embocadura do rio Majari, enquanto que do lado oposto, em igual extensão, os terrenos pertencem ao Sr. Araújo, conhecido por todos como J. G. Araújo. Esses dois homens são chefes de dois partidos opostos, nas suas mãos parecem repousar os destinos imediatos da população do Rio Branco $^{20}$.

Sabe-se que os coronéis instalados ou titulados durante a primeira República tinham particular apreço pelas publicações jornalísticas ${ }^{21}$. Estas pequenas folhas manifestavam alguma vocação política, para não dizer que, em sua boa parte, surgiam ligadas à intendência municipal, patrocinadas por políticos locais que se apresentavam

\footnotetext{
20 Apud. VIEIRA, Jaci Guilherme. Missionários, fazendeiros e índios em Roraima: a disputa pela terra 1777 a 1980. 2003. Tese (Doutorado). Programa de Pós-Graduação em História, Universidade Federal de Pernambuco, Recife, 2003, p. 100.

${ }^{21}$ MUNARO, Luís Francisco. Coronéis, jornais e a formação dos municípios no Amazonas. Revista Observatório, Palmas, 2018. Disponível em: https://sistemas.uft.edu.br/periodicos/index.php/observatorio/article/view/5223 (Acesso em 06/2021).
} 
como coronéis bacharéis, algo preocupados com o letramento, quer dizer, por cercar-se de uma auréola de elite intelectual. Em Boa Vista, a segunda destas folhinhas, "O Tacutu", confirma a vocação política se apresentando ligada ao mesmo coronel Brasil (figura 3). Tendo como redator "E-bion", seu primeiro número é de $1^{\circ}$ de março de 1907 e o último número de abril do mesmo ano. Infelizmente, as condições precárias do documento não permitem atestar com segurança o conteúdo do texto.

\section{FIGURA 3}

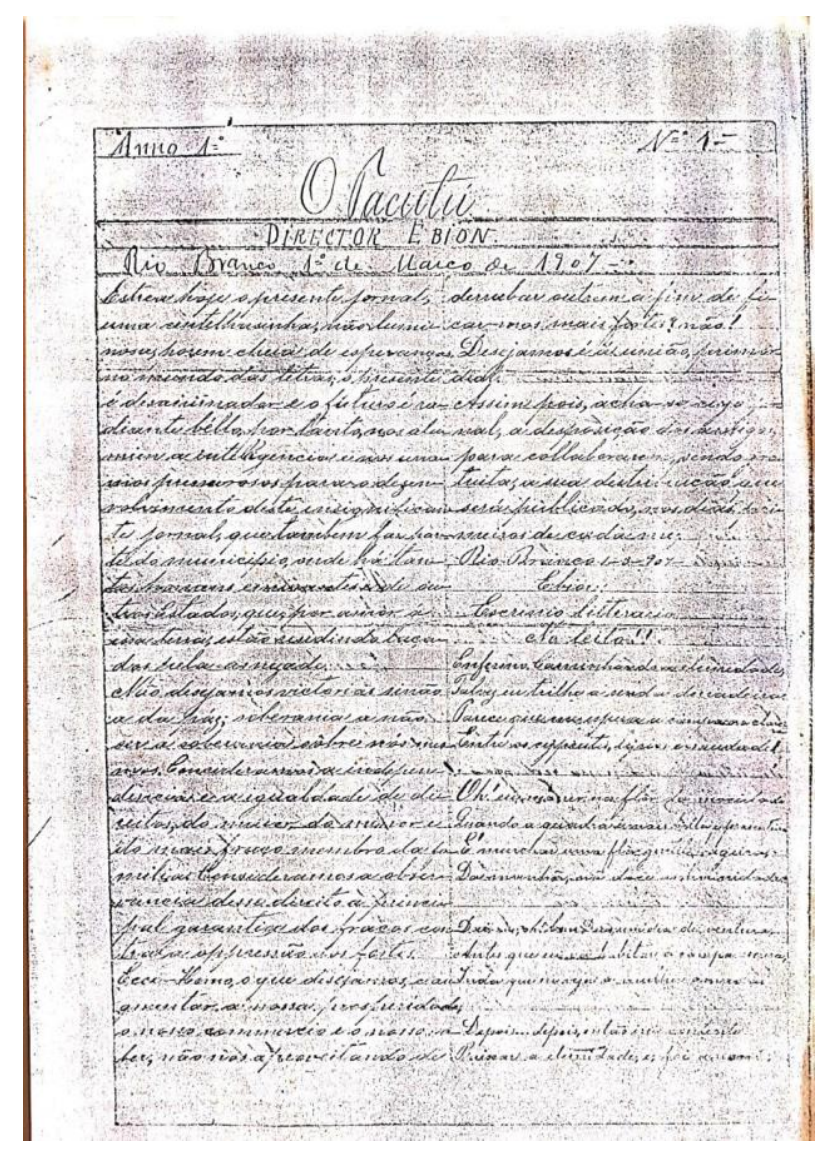

Jornal Tacutu, 1907. 914 X 1218, cor: tons de cinza (com a ação do tempo a cor tende a ser sépia), Fotografia retirada do exemplar disponível no Museu de Roraima, por Cyneida Correia.

Disponível: "JORNALISMO E MEMÓRIA: a construção da política nos jornais de Roraima (1907-1988)".

A terceira folha manuscrita, o jornal "A Escova" (figura 4), fugiu do tema da política local buscando dar publicidade àquela que talvez seja a segunda editoria preferida dos jornaizinhos do período, a vida social da vila. O redator-chefe se apresentava como "O Engraxate" e seu colaborador como "O Vigia". Também deste jornal apenas foi possível acessar uma edição de 1907. Conforme descrito por Cyneida Correia, o redator:

apresenta o jornal como crítico e literário que teria surgido a bordo do navio Madeira com o objetivo 'de defender as mulheres segundo seu comportamento'. No editorial, o jornal se apresentava como um 
periódico 'despido de bajulação, firme no seu ideal de defender os fracos (sic) dos que tentam macular a honra alheia'. No entanto, nas quatro páginas analisadas, o jornal fala sobre a sociedade, usando o humor e a sátira para citar adultérios, relações escusas e traições, criticando de forma intensa o comportamento feminino ${ }^{22}$.

Figura 4

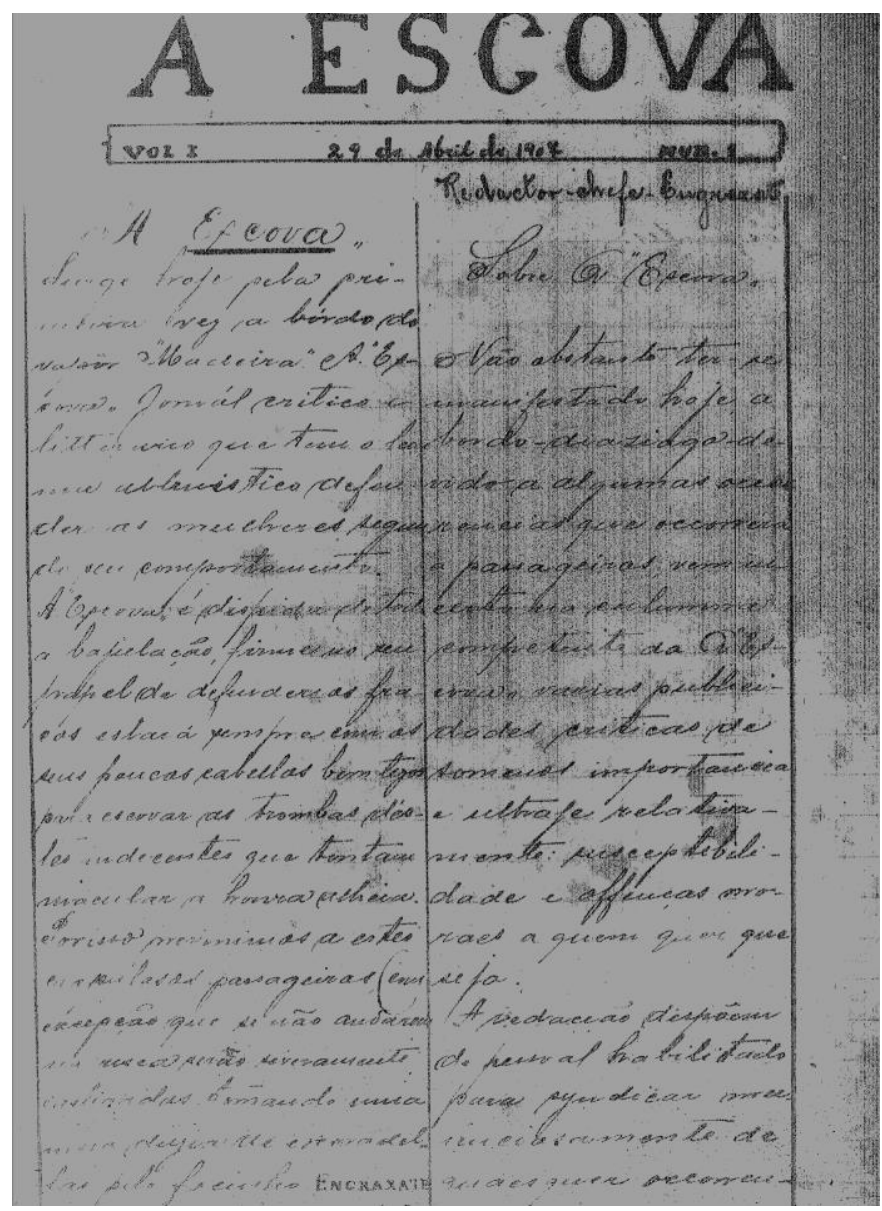

Jornal A Escova, 1907.914 X 1218, cor: tons de preto e cinza (a cópia existente está bastante apagada), Fotografia retirada de microfilmes existentes no acervo da Biblioteca Mário Ypiranga. Disponível: “JORNALISMO E MEMÓRIA: a construção da política nos jornais de Roraima (1907-1988)".

Como consta nesta edição, a "redação" dispunha de informantes na cidade, sempre prontos a abastecer o mexerico do jornal. Não se trata, evidentemente, do único registro de jornal produzido durante as longas viagens de navio nos rios da região amazônica. A título de informação, houve jornal impresso a bordo do vapor "Belo Horizonte" em 1918, no Rio Madeira ${ }^{23}$. Os mexericos locais abasteciam a vida destas pequenas comunidades

22 CORREIA, Cyneida Menezes. Jornalismo e memória: a construção da política nos jornais de Roraima (1907-1988). Dissertação de mestrado apresentada à Universidade Federal de Roraima, 2021, p. 50.

23 MUNARO, Luís Francisco (org.). Rios de palavras: a imprensa nas periferias da Amazônia. Porto Alegre: Editora Fi, 2016, p. 30. 
espalhadas ao longo da enorme e solitária rede hidrográfica do Amazonas. As poucas ocasiões sociais ofereciam um prato cheio para os fofoqueiros e, pode-se mesmo dizer, os encontros amorosos diziam respeito à própria sobrevivência destas comunidades com seus mil e tantos habitantes. Neste sentido, a referida proteção aos fracos e às mulheres reveste-se de uma atitude paternal, buscando apresentar à moça da boa sociedade os pares mais respeitáveis afastando as associações consideradas promíscuas.

\section{Os primeiros impressos de Roraima}

Na década de 1910, estão disponíveis três títulos de jornais impressos em Boa Vista: Rio Branco (1914), Jornal do Rio Branco (1916-1918) e O Rio Branco (1918). Além desta produção local, é muito provável que jornais impressos em Manaus fossem lidos na vila, como o jornal O Bemtivi, na sugestão feita por Cyneida Correia (2021). Segundo um dos pioneiros do jornalismo em Roraima, Murilo Bezerra, O Bemtivi tinha por função satirizar o cotidiano familiar dos moradores do Amazonas e do Rio Branco: "O Bemtivi era só mesmo para malhar as famílias e tudo. Ele era impresso em Manaus, as matérias saiam daqui... lá eram impressas e vinha circular aqui. Tinha até uma coluna assim, que dizia o bem-te-vi voando viu, aí baixava o malho" 24 . Apesar disso, nas edições deste jornal acessíveis não houve nenhuma menção direta a personalidades de Boa Vista ou mesmo ao município de Boa Vista.

Foi ao "Rio Branco, Jornal Independente", datado de 1914, que coube o título de pioneiro no jornalismo em Roraima. O jornal era impresso na Rua Sebastião Diniz, tendo como proprietários Alfredo Carmo Ribeiro e Diomedes Pinto Souto Maior, como administrador-gerente Ananias Linhares e Redatores Mizael Benedo, Artur Lago e Antonio Seabra. Este jornal já foi descrito, com alguma riqueza de detalhes, na obra "Rios de Palavras", fazendo-se necessário ainda compreender mais profundamente o papel destes jornalistas na condição de integrantes da elite local. O proprietário de jornal, educador e intendente Diomedes Pinto envolveu-se de perto com os debates sobre a formação do Brasil republicano tendo, no início do século, se deslocado para o Alto Rio Negro para missão educacional. Em 1905, já no hoje estado de Roraima, iniciou suas atividades de ensino na Fazenda Aramirá (município de Normandia), localizada nas proximidades do rio Maú de propriedade do Sr. Cavalcante Mello, para ao fim "se instalar em fazenda de propriedade de José Magalhães às margens esquerdas do Rio Branco, denominada São Lourenço"25. Segundo registros orais, o Prof. Diomedes recebia mensagens do exterior de Roraima através da Repartição Geral dos Telégrafos e esteve presente numa festa maçônica em que recebeu, em seu relógio, o selo da Maçonaria ${ }^{26}$. Portanto, Diomedes é um educador, político localmente importante e, como tal, um

\footnotetext{
${ }^{24}$ CORREIA, Cyneida Menezes. Jornalismo e memória: a construção da política nos jornais de Roraima (1907-1988). Dissertação de mestrado apresentada à Universidade Federal de Roraima, 2021, p. 53.

${ }^{25}$ BESERRA, Luiza Câmara, NASCIMENTO, Teresa Kátia Alves. Do pioneirismo à História: prof, Diomedes Pinto Souto Maior. Revista Debates. UFRR, 2000. Disponível em: http://revista.ufrr.br/index.php/textosedebates/article/view/993 (Acesso em 06/2021), p. 48.

${ }^{26}$ BESERRA, Luiza Câmara, NASCIMENTO, Teresa Kátia Alves. Do pioneirismo à História: prof, Diomedes Pinto Souto Maior. Revista Debates. UFRR, 2000. Disponível em: http://revista.ufrr.br/index.php/textosedebates/article/view/993 (Acesso em 06/2021, p. 50.
} 
homem de imprensa, ou que vê na imprensa a importância dos homens que se querem apresentar como ilustrados. Na condição de maçom, está integrado ao grupo do Coronel Bento Brasil, podendo-se mesmo dizer que trabalha em favor do poder daquele. A ilustração, neste contexto, seria a vontade destes indivíduos que levam, com sua presença, os poderes centrais nos cantos ainda "desabitados" do território brasileiro, garantindo a instalação da República. Em seu editorial, o jornal afirma que seu objetivo é:

Pugnar com o máximo fervor pelo progresso desta região de grandeza hipergênica; advogar com ardor cívico e dentro da esfera traçada pelo nosso direito público constitucional, a liberdade pessoal em todas as suas manifestações; combater com energia e à luz da legislação hodierna a marcha $* * *$ do crime, em uma palavra, lutar pelo direito - eis, em breve síntese, o polo que alvejamos ${ }^{27}$.

A linguagem adotada contém o mesmo ufanismo republicano que marca as publicações jornalísticas do período em toda a bacia amazônica. As leis iriam penetrar os lugares esquecidos permitindo uma era da razão. O uso da retórica grandiloquente é um recurso que se repete, desde os primeiros jornais do império demonstrando a estima em que os jornalistas viam a sua própria função de letrados e pedagogos. Sendo impresso em 1914, permanecemos ainda numa perspectiva de em torno de 100 a 200 leitores, estando entre eles os missionários, fazendeiros, pares políticos e ainda comerciantes, como se depreende dos anúncios. Mas, como de praxe na bacia hidrográfica, estes jornais eram enviados para outros municípios e integravam uma espécie de "esfera pública embrionária" da região ${ }^{28}$. A luta anunciada pelo interesse dos "pequeninos" contra os "potentados" significa, evidentemente, lutar pelo interesse dos coronéis locais contra a política estadual de Manaus ou então contra a política nacional da República e nada tem a ver com os indígenas. O coronel é visto como o elemento de progresso local, responsável por capturar recursos, abastecer o funcionalismo público e mediar conflitos. Como afirma o jornal:

Dentro do programa que traçamos, aparece hoje o primeiro número do Rio Branco. Ele será o cetro daqueles que sofrem a opressão dos potentados, será o disciplinador dos que se afastarem da linha dos seus deveres, na vida política e social. Filho de um esforço ingente, ainda que pequenino, é uma ideia transformada em realidade, $\mathrm{e}^{* * *}$ uma afirmação de que o querer é $\operatorname{poder}^{29}$.

As intrigas e disputas municipais ocupam boa parte da edição, elemento também revelador da política como traçada pela constituição de 1891 e o papel que nela coube às

\footnotetext{
${ }^{27}$ Rio Branco, Jornal Independente, Boa Vista, 15 de março de 1914, p. 1.

28 MUNARO, Luís Francisco (org.). Rios de palavras: a imprensa nas periferias da Amazônia. Porto Alegre: Editora Fi, 2016.

${ }^{29}$ Rio Branco, Jornal Independente, Boa Vista, 15 de março de 1914, p. 1, grifos nossos.
} 
municipalidades. A partir da formação do município de Boa Vista do Rio Branco em 1890, estas disputas se avolumaram. Com o crescimento populacional, mais indivíduos passaram a demandar posições de comando. No caso de Boa Vista, estes conflitos parecem estar mais nítidos em torno de fazendeiros e missionários, o que canalizava as energias dos proprietários em torno de uma pauta comum, muito embora, a partir de 1915, a situação tenha se tornado mais pacífica.

Além do conflito local, o município disputa a atenção dos poderes centrais e os jornais, porta-vozes da autoridade municipal, buscam ecoar como que solitariamente o "descaso" com relação à situação da periferia. Basicamente, estão a lamentar a ausência de incentivos ao povoamento "para esta fertilíssima região, [para a qual] revelaram o mais visível e condenável desprezo" ${ }^{30}$. Os redatores também descrevem os benefícios do clima de Boa Vista e o enorme potencial para o plantio e cultivo de gado. Como na obra "Colonisação e immigração, povoamento do estado do Amazonas", escrita pelo amazonense Torquato Tapajós e publicada em 1897, delineia-se como um tópos a ocupação dos "espaços vazios", tema constante nos relatórios dos administradores de província e a partir do final do século uma reivindicação generalizada das elites interiorizadas. Torquato deixava "implícita a noção de que as populações, vistas como que um material humano, podiam ser combinadas, educadas, transformadas pela ação política para melhor ocuparem ou 'engrandecerem' o espaço da nação, transformando-se em conjunto com a natureza para nesta se encaixar" 31 . O jornal busca, assim, ser um veículo destas reivindicações locais pela civilização, como aconteceu com tantas outras pequenas folhas ao longo da bacia hidrográfica do Rio Amazonas.

Com preocupações semelhantes, o "Jornal do Rio Branco: Órgão dos interesses dos moradores de Boa Vista", jornal mensal criado em 1916 pelos monges beneditinos e impresso na Igreja Matriz, possuía espaços para a doutrina e propagação da religião católica. Entre os missionários, como se depreende da leitura do seu opúsculo, estava um receio quanto às práticas de religiões consideradas desviadas, inclusive o espiritismo. Seus proprietários declarados eram Dias Medeiros e Misael Guerreiro da Prelazia do Rio Branco, este último mencionado pelo jornal $\mathrm{O}$ Rio Branco, um ano depois, como Intendente Municipal, o que sugere que não havia tensão política entre a intendência municipal e este projeto jornalístico. Entre os diretores constavam Geraldo O. S. B.Prelado do Rio Branco e Dr. Arthur Virgílio do Carmo Ribeiro - Juiz de Direito. Entre os principais redatores, Pe Boaventura Barbier, Vigário Geral; Paulo Eleutherio e Bezerra de Moraes.

O jornal possuía quatro páginas divididas entre as colunas fixas "Parte Editorial", assinada pelo bispo Gerardo von Caleon; "Parte Diocesana", com reflexões sobre o espiritismo e divulgação dos nomes das pessoas que contribuíram com esmolas para a Matriz; "Parte Variada", com decretos municipais e audiências públicas e, por fim, as colunas de informações nacionais e internacionais "Várias Notícias do Brasil" e "Várias

\footnotetext{
${ }^{30}$ Rio Branco, Jornal Independente, Boa Vista, 15 de março de 1914, p. 1.

${ }^{31}$ MUNARO, Luís Francisco. A civilização do Amazonas no pensamento de Torquato Tapajós (18531897). Canoa do Tempo. Revista do Programa de Pós-Graduação em História da Universidade Federal do Amazonas Volume 12, número 1, jan./jun. 2020. Disponível em https://www.periodicos.ufam.edu.br/index.php/Canoa do Tempo/article/view/7236 (Acesso em 06/2021) , p. 359.
} 
Notícias do Estrangeiro". A assinatura do Jornal do Rio Branco acontecia na Casa Sempre-Serve pertencente ao cidadão Misael Guerreiro que, além de um dos redatores do jornal, também apareceu como redator do "Jornal Itacoatiara: Semanário independente, noticioso e de propaganda", que circulou em 1874 em Itacoatiara.

\section{Figura 5}

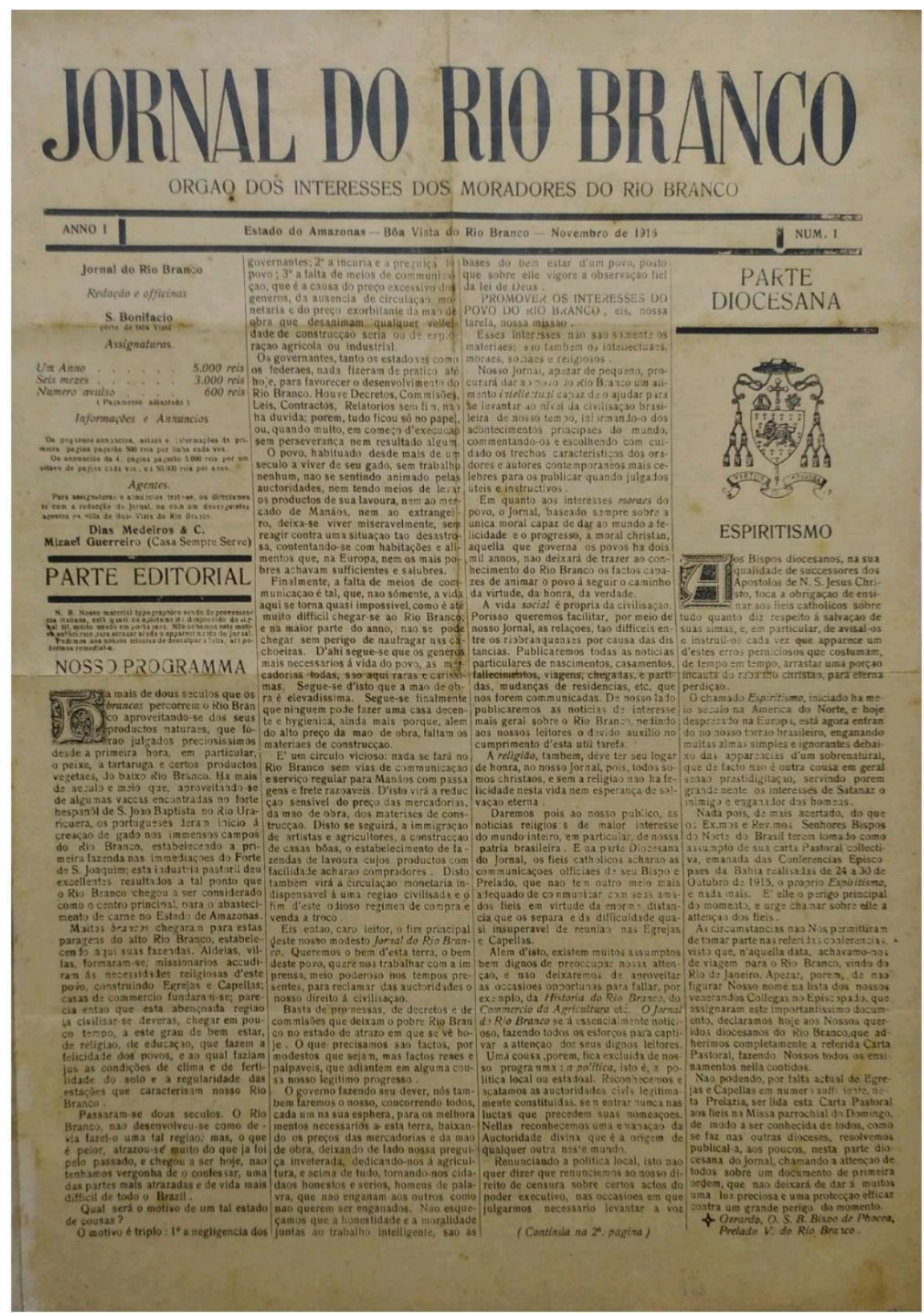

Jornal do Rio Branco, 1916/1917. Fotografia retirada de exemplares existentes no acervo da Biblioteca Mário Ypiranga Monteiro, localizada no Centro Cultural dos Povos da Amazônia (CCPA) Foto: Cyneida Correia.

A Igreja, núcleo da vila, também orientava o caráter da publicação, buscando assimilar os vários habitantes do lugar. $\mathrm{Na}$ condição de componente da microesfera pública, o jornal colocava os habitantes de Boa Vista e localidades próximas em conexão 
uns com os outros: o jornal, pela leitura regular, por constituir um enredo que diz respeito ao futuro de todos aqueles que o leem, protagoniza assim a formação de uma "consciência", um sentimento de participação comum. Daí a sua importância. Esta conexão não se dava apenas entre os habitantes da vila, mas entre eles e a República, o Brasil que estava sendo forjado. Na condição de missionários, por outro lado, os monges buscavam inserir a religião no cotidiano, atuando como um elemento de racionalização das ações, pacificação dos instintos e impulso para a vida ordeira.

Como apresentado no editorial de Gerardo Von Caloen, o dever do jornalista, tanto quanto o do bispo, seria contribuir para o desenvolvimento material e espiritual da comunidade. Assim, o redator ensina desde como, na condição de "jornalista em seu estrito dever", evitar o contágio de doenças fervendo a água, estimular o comportamento patriótico e religioso, desenvolver uma moral mais ou menos uniforme e conforme aos ensinamentos cristãos. Esta será uma preocupação comum de Gerardo também na Sociedade de Melhoramentos, na qual sempre enfatizou as questões de salubridade do Rio Branco como elemento fundamental para a povoação e colonização.

Também marcam o jornal conflitos com a doutrina kardecista, que se presume desenvolvia-se entre elementos maçônicos já presentes na região. Na parte diocesana, o jornal dedicava-se mais estritamente ao ensinamento da doutrina. Dada a imagem arranhada dos padres na vila, percebidos não incomumente como gananciosos e exploradores, a tipografia tinha também o objetivo de refazer sua reputação, reforçando os vínculos do boa-vistense com as iniciativas beneditinas de organização social:

os padres não são estes inimigos do povo, malfeitores e gananciosos, como muitos aqui no Rio Branco, pervertidos por más feituras, e sem o acreditarem eles mesmos, o dizem publicamente; $2^{\circ}$ que a representação do Prelado do Rio Branco, feita em 1909, era bem fundada a tal ponto que foi atendida pela dita Assembleia, e que escapamos assim, no Rio Branco, a mil misérias e dificuldades administrativas, a não falar nos erros do Correio $^{32}$.

O jornalista e bispo admitia ser seu dever, em primeiro lugar, o serviço prestado à religião católica e, num segundo, o amor devotado à pátria. Assim, suas atividades exigiam bastante preparo intelectual na hora de evitar o risco de contágios com o espiritismo: "Somos patriotas assim como somos católicos. Nosso dever é amar a Pátria, sustentá-la, defender sua honra, como amamos e defendemos a Santa Igreja Católica nossa mãe" ${ }^{33}$. Os costumes sincréticos, desviados da conduta orientada pelo catolicismo do Vaticano, eram vistos como perigosos para a construção da cidade. Não apenas os costumes estariam se desviando do catolicismo quanto os diversos elementos de outras formas de religiosidade presentes na região estariam impossibilitando a formação de famílias católicas ou elementos leitores de classe média. O bispo, assim, fazia o alerta:

\footnotetext{
32 Jornal do Rio Branco: Órgão dos interesses dos moradores de Boa Vista, Abril/Maio de 1917, p. 3.

33 Jornal do Rio Branco: Órgão dos interesses dos moradores de Boa Vista, Junho de 1917, p. 1.
} 
Qual será o fim de uma geração que amanhã virá a ser a população de uma cidade, desde que seus pais sejam homens corruptos, homens sem escrúpulos, homens sem moral e que não procuram aprender com os mais moralizados o bom caminho da moral ${ }^{34}$.

Evidentemente, educar-se a partir dos padrões morais católicos e urbanos implicava num esforço sistemático de alfabetização por parte das autoridades. De nada adiantaria o bispo tentar inserir "doutrinas corretas" no cotidiano da população se essa sequer estava apta para a leitura. Dada a negligência das autoridades com relação a estes benefícios do letramento, o bispo previa a formação de várias gerações de "idiotas úteis", ou "analfabetos perfeitos":

Nunca se falou tanto no analfabetismo e na necessidade de combatê-lo pelo ensino público, como nos nossos tempos. Nunca, porém, foi tão negligenciado o ensino público, no nosso Rio Branco como agora. E é de prever, que, se as coisas não mudarem, ou se o ensino particular não chegar a substituir o ensino público, teremos em breve aqui uma geração de analfabetos perfeitos, o que não constitui título de glória ${ }^{35}$.

A influência espírita, o analfabetismo, o candomblé, a mancebia com as índias, a bebedeira, enfim, a distância do catolicismo fazia com que o bispo lamentasse também a o isolamento cada vez maior da vila de Boa Vista e sua incapacidade de se conectar ao corpo da nação. Nas poucas vezes, nesse sentido, em que o governador do estado Pedro Bacellar (1917-1921) fez menção em aparecer, foi saudado como se fosse uma substância regeneradora, pronta a, com sua presença politicamente poderosa, ajudar a colocar a vila nos eixos:

De diversas pessoas que falaram com o Exmo. Dr. Pedro Bacellar, Governador do Estado do Amazonas, soubemos que S. Ex. mostrou grande interesse para com nossa região do Rio Branco, e pretende até nos visitar brevemente, talvez já no mês de junho que vem. Nenhuma notícia podia nos ser mais agradável. Pois, além do nosso prazer e da honra que todos teremos em conhecer a primeira autoridade do Estado, e de entrar em relações pessoais com ele, podemos estar certos de que, uma vez conhecendo a situação desta terra, ele não deixará de empregar seus esforços para melhorar as condições de vida no Rio Branco. Seja bem-vindo o Exmo. Sr. Governador ${ }^{36}$.

Enfim, a distância política dos centros de poder decisório foi percebida como um dos principais problemas para a civilização no sertão. As utopias construídas pelo bispo são sempre narrativas vinculadas aos projetos de construção de autoestradas, portos e

\footnotetext{
34 Jornal do Rio Branco: Órgão dos interesses dos moradores de Boa Vista, Março de 1917, p. 4.

35 Jornal do Rio Branco: Órgão dos interesses dos moradores de Boa Vista, Abril/Maio de 1917, p. 1.

${ }^{36}$ Jornal do Rio Branco: Órgão dos interesses dos moradores de Boa Vista, março de 1917, p. 3.
} 
ferrovias, únicos instrumentos capazes de fazer a nação republicana penetrar em Roraima exercendo a vocação, segundo o bispo, de a Amazônia se tornar o "celeiro do mundo".

O último dos jornais mapeados tem como título "Rio Branco, Órgão hebdomadário, literário, noticioso e comercial". ${ }^{37}$ Seu editorial apresenta o jornal como outro projeto civilizatório: "por entre as mais fundadas e legítimas esperanças do que é natural, inicia hoje, 'O Rio Branco' a sua vida de imprensa indígena, como periódico hebdomadário que se propõe a defender na medida de suas forças, os interesses gerais dessa opulenta região" "38. As notícias se dividem entre notas sobre a Primeira Guerra Mundial, em sua fase final, e a crise da borracha, em sua fase mais crônica.

\section{Figura 6}

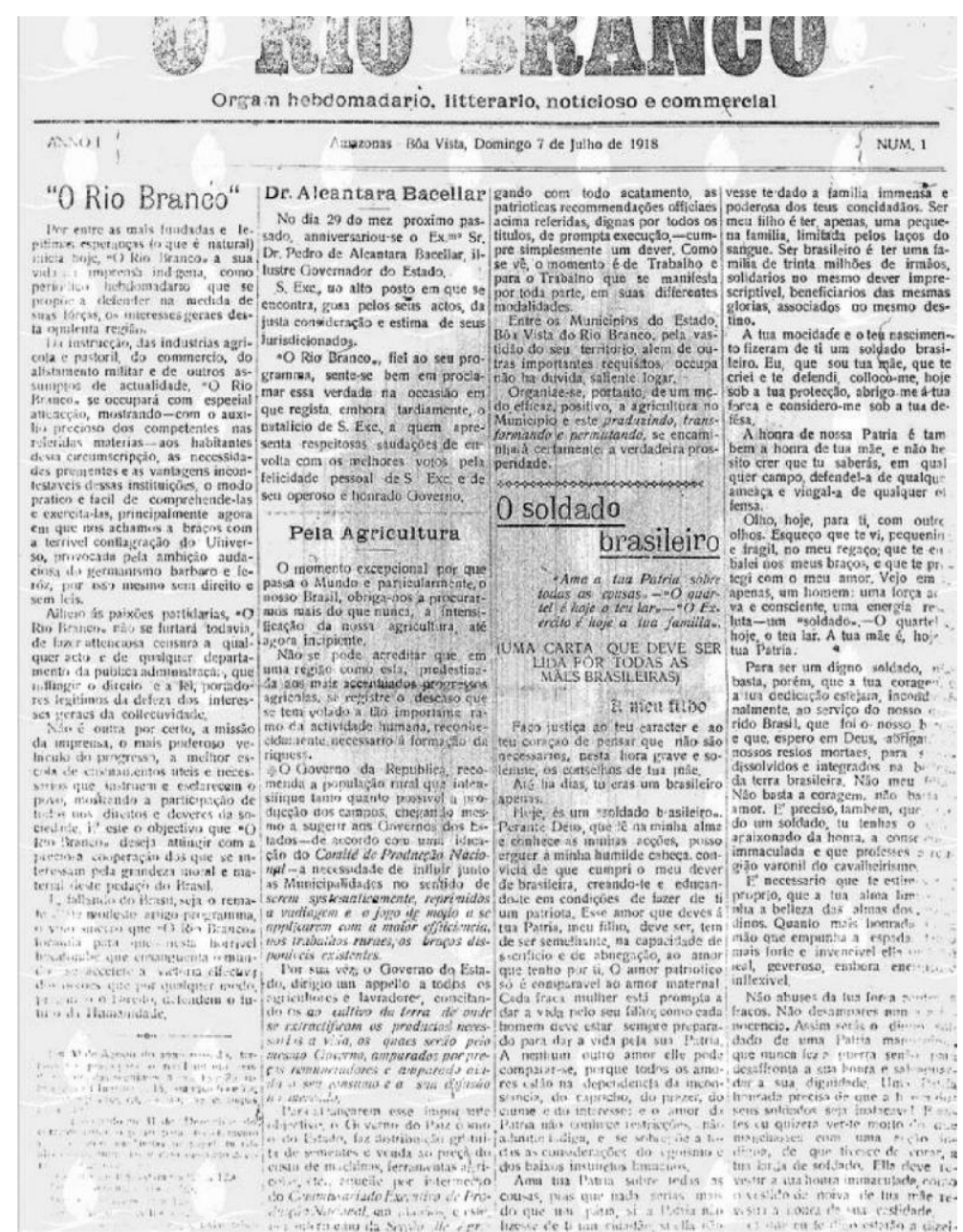

Imagem fac-similar - Frontispício do jornal Rio Branco, 07 de Julho de 1918. Fonte: Acervo digital da Biblioteca Mario Ypiranga.

\footnotetext{
${ }^{37} \mathrm{O}$ administrador é, mais uma vez, Ananias Linhares: “Todo negócio relativo à parte mercantil poderá ser tratado com o respectivo gerente e administrador das oficinas, Sr. Ananias Linhares. Aceita-se colaboração de interesse geral, não sendo devolvidos os autógrafos caso não sejam publicados. Redação e oficinas - Rua Sebastião Diniz. Boa Vista. Rio Branco. Amazonas" (14 de julho de 1918, p. 2)
}

${ }^{38}$ O Rio Branco, 7 de Julho de 1918, p. 1. 
Da mesma forma que seu predecessor homônimo, o jornal reclama a falta de atenção das autoridades centrais, mesmo com os recentes progressos de Boa Vista nas atividades agropecuárias ${ }^{39}$. Para os editores, somente o trabalho poderia impulsionar a vila rumo à civilização, afastando seus habitantes do contágio com "doutrinas erradas", numa fórmula bastante próxima à dos prelados capitaneados por Gerardo Von Caloen. $\mathrm{O}$ jornal menciona, inclusive, os "jogos de morto" (possivelmente alguma prática espírita ou umbandista):

O Governo da República recomenda à população rural que intensifique tanto quanto possível a produção dos campos, chegando mesmo a sugerir aos Governos dos Estados - de acordo com uma indicação do Comité de Produção Nacional - a necessidade de influir junto às Municipalidades no sentido de serem sistematicamente reprimidos a vadiagem e o jogo de morto a se aplicarem com a maior eficiência, nos trabalhos rurais, os braços disponiveis existentes ${ }^{40}$.

As notícias de chegadas e partidas neste jornal são constantes. Referem-se ao interior do estado, rumo a Caracaraí ou Mucajaí, ao norte na fronteira com a Guiana e, sobretudo, Manaus, para onde os cidadãos ilustres partem constantemente. Um desses indivíduos chegados recentemente foi "o Sr. Diomedes Pinto Souto Maior, que na qualidade de Intendente Municipal, vem tomar parte na reunião do Conselho marcada para o dia 14 do corrente" 41 . Nestas duas edições, ora Diomedes, ora Misael Guerreiro aparecem como Intendentes. Outro acontecimento ilustre diz respeito à chegada de Manaus, na lancha Ajuricaba, "do Sr. Coronel Bento Brasil, abastado fazendeiro e comerciante nesta vila. O Sr Coronel Bento Brasil que foi àquela capital *** interesses comerciais *** Ao digno cidadão as nossas afetuosas saudações"42. Através das referências constantes aos habitantes locais, sobretudo aos mais ilustres, o jornal vai reforçando os círculos de sociabilidades em Boa Vista e montando um espaço que constituiria uma espécie de apresentação da elite e reforço do status quo destes fazendeiros. Na edição de 14 de julho, o jornal comenta a positiva recepção que teve entre os moradores, mencionando também as várias visitas recebidas nos dias anteriores. Os indivíduos mencionados são pelo menos 20, distribuídos em categorias como fazendeiros, comerciantes, advogados e autoridades públicas. Quatro deles possuem patente militar, sendo 3 delas de coronel: Coronel Manoel Pereira Pinto, Capitão Manoel Lopes de Magalhães, Coronel José Magalhães, Tenente-coronel João Capistrano da Silva Mota.

Mais importante, nestas primeiras edições, é o reconhecimento do término daquele que foi o maior empreendimento impresso de Boa Vista até pelo menos a década de 40, o jornal dos monges beneditinos "Jornal do Rio Branco". É este reconhecimento que também permite precisar a extensão de tempo que durou o predecessor, dada a disponibilidade nos arquivos apenas de edições de 1916 e 1917:

\footnotetext{
${ }^{39}$ O Rio Branco, 7 de Julho de 1918, p. 1.

40 O Rio Branco, 7 de Julho de 1918, p. 1, grifos do autor.

${ }^{41}$ O Rio Branco, 7 de Julho de 1918, p. 2.

42 O Rio Branco, 7 de Julho de 1918, p. 2.
} 
Por motivo de força maior, está suspensa desde fevereiro passado a publicação do nosso colega, o Jornal do Rio Branco, órgão mensal defensor dos interesses dos moradores do Rio Branco, que se edita sob a competente direção do Exmo. Sr. D. Gerardo de Caleon. São os nossos votos que se ative o reaparecimento do nosso ilustre confrade, que muitos benefícios vinha prestando à população deste município ${ }^{43}$.

Outra referência feita a D. Gerardo de Caleon diz que o bispo foi "acometido de febre palustre", desejando-lhe a mais breve recuperação ${ }^{44}$. Essa breve troca de gentilezas ajuda a demonstrar que as primeiras tensões entre beneditinos e fazendeiros haviam sido ultrapassadas com a diplomacia de Gerardo. Por fim, nos seus anúncios publicitários, o jornal também ajuda a perceber as presenças do Coronel Bento Brasil e do comerciante J. G. Araújo, atuando, assim, como um espaço de amortecimento das tensões que certamente dificultavam a vida de uma elite política e econômica em processo de formação.

\section{Considerações finais}

O processo de letramento em lugares isolados da Amazônia contou com o protagonismo de indivíduos que, vencendo circunstâncias um tanto precárias, conduziram atividades educacionais em conjunto com pequenos grupos de estudantes. Tanto Diomedes Souto Maior quanto Gerardo Von Caleon foram exemplos disso. Tais atividades de letramento permitiram a formação de um pequeno público leitor de jornais.

As atividades intelectuais, pelo menos aquelas escritas, compreendidas também elas como um exercício de poder, costumavam orbitar em torno dos coronéis no esquema característico do que Vitor Nunes Leal intitulou coronelismo: as autoridades locais angariavam votos, administravam recursos, arbitravam conflitos e revertiam isso em respaldo político para o governador. Daí que, na condição de um exercício de poder na pequena vila, capaz de garantir legitimidade de um grupo político, o jornal constantemente elogiava o indivíduo local mais poderoso, o Coronel Bento Brasil.

Num primeiro momento, estes jornais da vila de Boa Vista do Rio Branco eram em torno de 6 ou 7 títulos de folhas manuscritas, até serem substituídos na década de 1910 por jornais impressos cuja circulação logo se viu interrompida. Presume-se, no contexto dessa interrupção, que jornais provenientes de Manaus tenham sido mais eficientes não só de noticiar a vida das elites locais como também de conectá-las com o grande espaço do estado. Dado mesmo o pouco alcance do processo de letramento local, presume-se que a circulação de tais jornais ficava confinada a um pequeno círculo de letrados, entre os quais as famílias de fazendeiros onde se dava também o ensino doméstico das letras, como relatado pelo etnógrafo Theodor Koch Grunberg.

\footnotetext{
${ }^{43}$ O Rio Branco, 7 de Julho de 1918, p. 3.

${ }^{44}$ O Rio Branco, 7 de Julho de 1918, p. 3.
} 
No contexto nacional de ufanismo republicano, os jornais manifestavam o seu apreço pelas iniciativas estatais de controle do território, capazes de moldar uma consciência nacional conectada com outras nações cuja história e consciência já se encontravam consolidadas. Este processo de ingresso da região na nação foi comumente associado à civilização, e dele, nos interiores do Brasil, os partidos republicanos e seus jornaizinhos se consideravam porta-vozes grandiloquentes, expressivos "da vitória da civilização sobre a barbárie". No caso dos pequenos municípios amazônicos, de forma geral, as intendências municipais tinham à disposição máquinas tipográficas para a impressão dos atos administrativos e, ao mesmo tempo, publicação de notícias ou comentários políticos de interesse da administração. É com a diversificação da vida local, derivada inclusive do crescimento econômico e demográfico, que grupos concorrentes passaram a disputar a intendência e trocar farpas na estrutura dos jornaizinhos.

Estes, num cenário amazônico de relativa ausência de registros históricos numerosos, são fontes documentais de fundamental importância na medida em que espelham (refratando, evidentemente) o cotidiano das vilas mutantes, erguidas rapidamente nos anos da febre gomífera, que permitem não apenas entrever a rarefeita vida social de elites em processo de autoafirmação, como também a composição dos poderes políticos da primeira república. Dada essa condição de registro isolado da vida no sertão, estes jornais costumam exagerar (ou talvez não) a sua missão civilizatória, conectando os rincões isolados na consciência nacional nascente.

\section{Bibliografia:}

BARBOSA, Marialva, Os manuscritos do Brasil: cenários de uma escritura. IN: Anais do XXXVII Congresso Nacional de Ciências da Comunicação. Foz do Iguaçu, 2014.

BESERRA, Luiza Câmara, NASCIMENTO, Teresa Kátia Alves. Do pioneirismo à História: prof, Diomedes Pinto Souto Maior. Revista Debates. UFRR, 2000. Disponível em: http://revista.ufrr.br/index.php/textosedebates/article/view/993 (Acesso em 06/2021)

CANDIDO, Francisco. Personagem VIVA da nossa História: Cecy Lya Brasil Presidente da Academia Roraimense de Letras. Folha de Boa Vista. 12/04/2017. Disponível em: https://folhabv.com.br/coluna/Minha-Rua-Fala-12-04-2017/3900 (Acesso em 06/2021)

CANDIDO, Francisco. Portugueses no Vale do Rio Branco e outros fundadores de

Fazendas. Folha de Boa Vista. 26/04/2016. Disponível em: https://folhabv.com.br/coluna/PORTUGUESES-NO-VALE-DO-RIO-BRANCO-eoutros-fundadores-de-Fazendas-/2335 (Acesso em 06/2021)

CIRINO, C. A. M. A "boa nova" na língua indígena: contornos da evangelização dos wapischana no século XX. Boa Vista, EDUFRR, 2008.

JOAQUIM, Jupira Simões Sandova. Raposa Serra do Sol: Demarcação Territorial. Tese de doutorado apresentada à USP, 2003.

Jornal do Rio Branco, Boa Vista, 1917.

KOCH-GRÜNBERG, Theodor. Do Roraima ao Orinoco. V. I, São Paulo: Editora UNESP, 2003. 
LEAL, Vitor Nunes. Coronelismo, enxada e voto. São Paulo: Companhia das Letras, 2012.

CORREIA, Cyneida Menezes. Jornalismo e memória: a construção da política nos jornais de Roraima (1907-1988). Dissertação de mestrado apresentada à Universidade Federal de Roraima, 2021.

MUNARO, Luís Francisco (org.). Rios de palavras: a imprensa nas periferias da Amazônia. Porto Alegre: Editora Fi, 2016.

MUNARO, Luís Francisco. A civilização do Amazonas no pensamento de Torquato Tapajós (1853-1897). Canoa do Tempo. Revista do Programa de Pós-Graduação em História da Universidade Federal do Amazonas Volume 12, número 1, jan./jun. 2020. Disponível

https://www.periodicos.ufam.edu.br/index.php/Canoa_do_Tempo/article/view/7236

(Acesso em 06/2021)

MUNARO, Luís Francisco. Coronéis, jornais e a formação dos municípios no Amazonas. Revista Observatório, 2018. Disponível em: https://sistemas.uft.edu.br/periodicos/index.php/observatorio/article/view/5223 (Acesso em 06/2021)

NETO, Manuel Aires da Silva. Migração de nordestinos para o vale do Rio Branco (RR) entre 1890 e 1930. Monografia apresentada na UFRR, 2011.

NETO, Vanthuy. História cronológica dos bispos de Roraima. S/d Disponível em: https://diocesederoraima.org.br/index.php/diocese-2/ (Acesso em 06/2021)

O Rio Branco, Boa Vista, 1914.

O Rio Branco, Órgão hebdomadário, literário, noticioso e comercial, Boa Vista, 1918.

OLIVEIRA, Sebastião Monteiro. Origem e organização do sistema de ensino e as políticas de formação docente no estado de Roraima. Tese de doutorado apresentada na UNINOVE. 2016. Disponível: https://bibliotecatede.uninove.br/handle/tede/1538 Jun/2021.

RICE, Hamilton. Exploração na Guiana Brasileira. Belo Horizonte/São Paulo: Ed.Itatiaia/EDUSP, 1978

SANTOS, Francisco Jorge. Cem anos de imprensa no Amazonas. (1851-1950). Catálogo de jornais, Manaus: 1990.

SANTOS, Roberto. História econômica da Amazônia. 1800-1920. São Paulo: T.A. Queiroz, 1973.

SIEMS-MARCONDES, Maria Edith. "Educação em Roraima: Institucionalização escolar de 1943 a 2001". Revista História e historiografia da educação. 2017. Disponível em https://revistas.ufpr.br/rhhe/article/view/50778 Jun/2021.

VIEIRA, Jaci Guilherme. Missionários, fazendeiros e índios em roraima: a disputa pela terra - 1777 a 1980. 2003. Tese (Doutorado). Programa de Pós-Graduação em História, Universidade Federal de Pernambuco, Recife, 2003.

Data de submissão: $07 / 10 / 2021$

Data de aceite: 18/12/2021. 